\title{
Research on Specialist Setup of Vocational Colleges with Regional Economy Coordinated Development
}

\author{
Lina Zhao \\ Handan Polytechnic College \\ Handan, China \\ Zhaolinamv@163.com
}

\begin{abstract}
Specialty setup is not only the tie between vocational colleges and regional economic development, but also one of the core steps of vocational education reform. In recent years, higher vocational education in China has made considerable progress, however we must be soberly aware that there would be a serious demand of skills-based and applied workers with the industrial transformation and upgrade as well as the strategic adjustment of economic structure. But the Specialty Setup to some extent can not satisfy this great demand. Nowadays, there are a lot of studies on the relationship between higher education and regional economy. Also, lots of professors do the research of major setup in universities. Therefore, $I$ analyze the issues in current Specialty Setup of Vocational Colleges, and then I made a point that Specialty Setup should be coordinated with the regional economic development, and corresponding countermeasures to solve this problem [1].
\end{abstract}

Keywords-vocational colleges; specialty setup; regional economy; sustainable development; strategy.

\section{INTRODUCTION}

There are some divergences exist in the sustainable development of Specialty Setup, which is sited up in Vocational Colleges currently. Those divergences which are embodied in positioning specialties, choosing development strategy, school orientation, regardless of the development of the regional economy, cause low employment rate, and atrophied specialty gradually shrinks to disappear. More serious, Specialist Setup is unable to meet a variety of needs of the regional economic development. Therefore, it is necessary that analysis and research in higher vocational colleges professional setting and the regional economic interdependence symbiotic relationship.

\section{PRoblems In Specialty SetuP}

\section{A. Non-standard professional name}

With the expansion of the scale of higher vocational colleges, the number of specialty is more and more large. However, most specialties are only different in name, to the teaching process and the education curriculum there is on difference. Non-standard professional name generated much harmful influence on students, colleges, and companies. On one hand, it is very difficult for education administrative departments to analysis the relationship between Specialist Setup of Vocational Colleges and Regional Economy [3]. So that Specialist Setup can not be used for regional economic growth. On the other hand, Non-standard professional name bring trouble for students in the choice of professional and inconvenience for the business and other employers to choose talent. What the typical specialist are Mold Design and Manufacture Plastic Mold Design and Manufacturing; Communications Technology and Communications Networks and Devices; Computer Communications and Computer Communication Technology and so on [2].

\section{B. Lacking of corporate participation in Specialty Setup}

Vocational colleges which attach great importance to vocational college students' training are generally lack of communication between companies in the process of setting specialties. So there is still "hot school enterprise cold" embarrassing situation in the school-enterprise cooperation. Reasons can be divided into two aspects that are college and company. For colleges, first few schools make in-depth investigation, analysis, infrequently inviting experts to conduct feasibility studies; second schools rarely listen to the opinions that be put forward from industry, business and other persons; last but not least, vocational colleges, blindly follow other vocational colleges when creation of professional, without taking their own school conditions and which mature industry group are in the area where they are located in into account [1]. For companies, why they do not have higher motivation is that they are only focus on the immediate benefit.

\section{Be similar with undergraduate professional setting}

Characteristic do not be reflected in specialist setup of vocational colleges. To start with, an undergraduate professional is subdivided into various aspects of the work and career or a corresponding number of specialties [3]. In addition, specialist setup of vocational colleges only makes a minor amendment from the undergraduate professional, whereas the personnel training objectives, course content, curriculum and other unchanged, even the ordinary undergraduate institutions directly used as Higher Vocational Education Specialist. Vocational Education makes a "vocational not high, occupation is not exclusively" phenomenon, difficult to reflect sustainability [4].

The building in some majors about hardware and software should be strengthened and improved further. The main problem reflected in following areas. On the one hand, Chinese Vocational colleges get less funding and have less qualified 
teacher than average and the teachers are lack of practice. Moreover, dedicated, part-time teachers structure is not reasonable, In other words the "Double" teacher ratio is less. On the other hand, on account of shortage of professional training conditions, it is hand for students to participate in simulation practice in campus and the post teaching practice, especially for students who are from Literature and economics majors.

\section{Connotation in Specialty is blurred}

Some Majors names have unclear direction and goals in personnel training. It is difficult to figure out the professional employment opportunities and employment orientation, without the aid training objectives, curriculum, teaching programs. The main reason for this is that the setting and teaching of specialties at universities fall short of demands of comprehensive quality and skills for personnel's by relevant vocational posts. Such as International Economics and Trade, Law, Administration and other professional, although people feel easy to understand the professional name, but for the connotation of name, it is hard to accurately understand students who trained are geared exactly for what jobs.

\section{COUNTERMEASURES ON SPECIALIST SETUP OF VOCATIONAL COLLEGES WITH REGIONAL ECONOMY COORDINATED DEVELOPMENT}

\section{A. Specialist Setup should be standardized}

First and foremost, vocational colleges which do not have conditions to set a specialist, which goal is just recruiting students easily should be corrected. Moreover, it is essential that the authorities should work out and implement relevant laws and regulations to put to make professional name standardized, strictly define the scope of the specialist which are same or similar and with little difference in the same direction.

To make overall plans regarding the layout structural adjustment and introduction to specialties of higher schools of district.

\section{B. Strengthening school-enterprise cooperation}

The market of taking jobs is the adjustment of students' resource, the establishment of specialty, fostering standard and teaching quality.

Firstly, training of double-certificate teachers at colleges should be based on outstanding technical elites at the production line. So Vocational Colleges should invite the excellent professional and technical personnel who are from company to participate in the teaching. At the same time, teaching content should be consistent with industry trends and business needs, colleges and enterprise personnel should make joint efforts to develop new curricula and materials, only by doing these we can ensure the suitability of personnel training industry. Finally, teachers must pay attention to teaching practice, raise student's ability to apply theory to practice.

\section{Scientific Positioning of Specialty - training Goals}

Vocational Colleges should prioritize features like the goals of university development, disciplines and specialties, personnel training and scientific research. This is the premise of specialist setup of vocational colleges with regional economy coordinated development [4].

To begin with, a communication platform should be established for vocational colleges and regional economy to dynamically adjust the professional enrollment scale and professional development. On the one hand, we can establish a steering committee which composed of industry representatives, business representatives, relevant government department heads, vocational education experts, professional teachers in order to control the whole pulse of professional development.

Furthermore, we should establish a system with which the information about professional development relevant market is able to be regularly published and shared [3]. By taking this effective measure, the information of institutions, market demand, and industry can be shared promptly. In the premise of study the information related, the Steering Committee of Specialty construction will have the ability to make an early warning and control during the professional development timely.

\section{According to the regional economic development needs, giving old professional new connotation.}

New industrial structure adjustment, making some of traditional industries demand for talent direction changes, the traditional professional training direction should be adjusted accordingly along with, such as direction about the Computer Application Technology specialty group which around the construction of mobile communication before should adjust for mobile phone software ; [5]Television Animation around the building in a new eco-city animation base to develop in the direction of animation; Applied English Major with the development of tourism demand and foreign-funded enterprises will be divided into new business English and English direction of travel; Logistics Management professional with China International logistics Center will establish the status of the development of international logistics and port logistics direction.

\section{CONCLUSION}

Specialty setup in higher vocational colleges should meet the needs of the development of regional economy, which has a bearing on their serving the society and their own sustainable development. In theory, it is of great significance to successfully deal with the relationship between specialties offered in higher vocational colleges and coordinated development of regional economy, which can not only promote regional economic development, but also improve the quality of workers and enhance the comprehensive national strength. Based on the concept of sustainable development, this paper discusses some positive and effective strategies employed in specialties offered in higher vocational education in the aspects of transforming government functions, optimizing the structure of specialties and promoting the combination of production and learning [5]. 


\section{REFERENCES}

[1] Zuo Chao, "Coordinated development of specialty vocational colleges and regional economic research" [D]. Guangdong Polytechnic Normal University, 2012.

[2] Liang Aiwen, "path of innovation for Vocational Colleges - Based on the Perspective of Regional Economic Development” [A] Yunnan Provincial Institute of Higher Vocational Education Branch 2008 Outstanding Proceedings [C]:, 2008:... 6.

[3] Wang Jing, "Hebei Higher Professional Education and the regional economic development compatible with the” [D]. Hebei Normal University, 2013.

[4] Gai Fu, "explore the forest of osmanthus and professional development of vocational regional economic interaction” [J] Chinese Vocational and Technical Education, 2013,08: 70-73.

[5] Hou Ning, Sha Qiulin, Guo Kuiyu, "professional setting and the coordinated development of regional economy Vocational Colleges" [J]. Journal of Wuxi Institute of Commerce and Technology, 2013,02: 59-62 